\title{
ŚWIADOMOŚĆ LINGWISTYCZNA (PRZYSZLYCH) LEKTORÓW JĘZYKA POLSKIEGO JAKO OBCEGO - KILKA UWAG O ZNAJOMOŚCI FLEKSJI IMIENNEJ
}

\begin{abstract}
Słowa kluczowe: gramatyka funkcjonalna, świadomość lingwistyczna, kompetencje nauczycieli, fleksja imienna, glottodydaktyka, język polski jako obcy

Streszczenie. Artykuł porusza zagadnienie świadomości lingwistycznej studentów - słuchaczy specjalizacji glottodydaktycznej na Wydziale Filologicznym Uniwersytetu Łódzkiego. W tekście zostały przedstawione i omówione wyniki analizy badania ankietowego przeprowadzonego w grupie 52 studentów. W kwestionariuszu umieszczono pytania dotyczące podstawowych problemów z gramatyki funkcjonalnej języka polskiego z zakresu fleksji imiennej, które omawiane są przez nauczyciela języka polskiego jako obcego podczas zajęć z cudzoziemcami. Analiza materiału badawczego zaowocowała propozycją wprowadzenia pojęcia glottodadaktycznej świadomości lingwistycznej, związanej ze specyfiką pracy nauczyciela języka obcego, będącej dopełnieniem świadomości lingwistycznej.
\end{abstract}

Celem niniejszego artykułu jest zbadanie świadomości językowej studentów specjalizacji Nauczanie języka polskiego jako obcego/drugiego dotyczącej fleksji imiennej, która rodzi najwięcej pytań wśród osób rozpoczynających pracę w zawodzie lektora. Wykładowcy metodyki nauczania języka polskiego jako obcego na każdych zajęciach rozwiewają wątpliwości studentów w zakresie funkcji biernika. dopełniacza, zasad dystrybucji narzędnika, miejscownika i celownika, łączliwości przyimków z różnymi przypadkami czy podstawowych konstrukcji składniowych. Studenci sami zauważają, że dobra znajomość zasad gramatyki opisowej pomaga sprawnie poruszać się w obrębie gramatyki funkcjonalnej.

Do badania posłużyła nam ankieta przeprowadzona wśród 26 studentów, którzy ukończyli specjalizację Nauczanie języka polskiego jako obcego (na potrzeby

*magdalena.karasek@uni.lodz.pl, Uniwersytet Łódzki, Wydział Filologiczny, Instytut Filologii Polskiej i Logopedii, Zakład Lingwistyki Stosowanej i Kulturowej, ul. Pomorska 171/173, 90-236 Łódź; mateusz.gaze@uni.lodz.pl, Uniwersytet Łódzki, Wydział Filologiczny, Instytut Filologii Polskiej i Logopedii, Zakład Lingwistyki Stosowanej i Kulturowej, ul. Pomorska 171/173, 90-236 Łódź. 
niniejszego opracowania nazwanych glottodydaktykami) oraz 26 studentów, którzy dopiero rozpoczęli zajęcia specjalizacyjne (tzw. nieglottodydaktycy). Studenci drugiej grupy nie ukończyli kursu metodyki nauczania jpjo, koncentrującego się na zagadnieniach gramatyki pedagogicznej.

Badanie dotyczyło zagadnienia świadomości językowej. Marian Bugajski definiuje świadomość lingwistyczną jako ,znajomość zasad budowy i rozwoju języka oraz reguł dotyczących posługiwania się nim" (Bugajski 2007, s. 48). Badacz odróżnia ją od tzw. świadomości językowej, która nie wymaga znajomości reguł systemowych (por. Bugajski 2007, s. 47). Cechuje ona językowych niespecjalistów, którzy, choć używają języka intencjonalnie, refleksyjnie, w ocenie rozmaitych form językowych kierują się przede wszystkim intuicją (por. Markowski 2005, s. 123-124; Bakuła 2012, s. 10). Świadomość lingwistyczna winna natomiast charakteryzować językoznawców, ekspertów, których sądy o języku umotywowane są naukową wiedzą lingwistyczną. Świadomość językowa byłaby więc pojęciem szerszym i przysługującym większej liczbie użytkowników polszczyzny. Wielu badaczy ogranicza się w swoich naukowych rozważaniach do wyróżnienia tylko pierwszego z pojęć, jednak wnikliwa lektura prac pozwala przyjąć, że zjawisko świadomości lingwistycznej, choć nienazwane w ten sposób, jest przez nich zauważane i opisywane. (por. Zgółka 1996; Maćkowiak 2005; Słaby-Góral 2014; Perużyńska 2005). Wydzielenie świadomości lingwistycznej wydaje się szczególne istotne w związku z założeniem niniejszego artykułu. Grupę badawczą stanowili bowiem użytkownicy języka, którzy z racji wybranego kierunku studiów powinni odznaczać się zarówno intuicją, jak i - popartą wiedzą - refleksją językową.

„Podstawę świadomości językowej stanowi wiedza intuicyjna” (Bakuła 2012, s. 10) Sama intuicja to jednak za mało, by sprawnie przekazywać wiedzę na temat języka, by być skutecznym nauczycielem języka. Nauczyciel musi zauważać relacje, umiejętnie wyrażać opinie, trafnie formułować reguły dotyczące systemu językowego. Andrzej Markowski zauważa, że świadomość językowa ujawnia się między innymi „w reakcjach rodzimych użytkowników języka (native speakerów) na zjawiska językowe” (Markowski 2005, s. 124). Jeśli ich refleksje są merytoryczne (nie ograniczają się do suchych stwierdzeń typu: Tak się nie mówi; To błą niepopartych argumentami lingwistycznymi), to mówimy o wysokim poziomie świadomości językowej. Podczas zajęć z metodyki nauczania języka polskiego jako obcego zdarzają się sytuacje, w których studenci, z powodu niewystarczającej wiedzy o systemie języka polskiego, nie próbują rozwiązać problemu językowego, stwierdzają, że danego zagadnienia nie da się wytłumaczyć, nie znajdują odpowiedniej zasady, gramatycznej reguły, którą mogliby wykorzystać na lekcjach z obcokrajowcami. Zdradzają w ten sposób niski poziom świadomości językowej, a jako przyszli nauczyciele języka polskiego jako obcego powinni cechować się świadomością lingwistyczną przysługującą językowym specjalistom. 


\section{Respondenci musieli zmierzyć się z następującymi zagadnieniami:}

- Dlaczego przymiotnik niebieski ma końcówkę fleksyjną - $i$, a przymiotnik dobry -y?

- Dlaczego w bierniku mówimy: Jan ma komputer, ale Jan ma syna?

- Dlaczego mówimy: Ania jest sympatyczna dziewczynq (narzędnik), ale Ania to jest sympatyczna dziewczyna (mianownik)?

- Dlaczego mówimy: Ania lubi pizzę (biernik), ale Michat nie lubi pizzy (dopełniacz)?

- Dlaczego mówimy: Kasia pojechała na grzyby (biernik), ale Kasia była na grzybach (miejscownik)?

- Dlaczego mówimy: Magda opalata się nad rzeka (narzędnik), ale Magda poszła nad rzeke (biernik)?

- Dlaczego mówimy: Poszedtem do szkoty, ale Poszedtem na boisko?

- Dlaczego mówimy: Poszedtem do baru, ale Poszedtem na piwo?

- Dlaczego mówimy: 27 lat, ale $42 \underline{\text { lata }}$.

- Dlaczego uczący się języka polskiego jako obcego może popełnić błąd i powiedzieć: Jan jest dobrạ mężczyzną?

- Proszę określić przypadek podkreślonych rzeczowników:

a) Lubię koty. .

b) Mam zadanie do zrobienia.

c) Wspominam swoje liceum

d) Piszę sms.

e) Gazeta leży pod stołem.

f) Potrzebuję dwóch studentów do pomocy

g) Spaceruję po parku.

h) Szedł ku bramie.

i) W pracy używam języków obcych.

j) Samochód stoi przed kinem

k) Matka fotografuje synów.

1) Kocham brata.

- Proszę określić rodzaj następujących rzeczowników:
a) muzeum -
b) pies -
c) woda -
d) studentki -
e) inżynierowie -
f) doktor -
g) fajtłapa -
h) koty -
i) chłopaki - 
Kwestionariusz otwierało pytanie dotyczące końcówek fleksyjnych przymiotnika. Jest to jeden z pierwszych problemów gramatycznych, z którym stykają się obcokrajowcy. Końcówki przymiotnika uzależnione są od rodzaju rzeczownika i spółgłoski wygłosowej w rodzaju męskim i nijakim ${ }^{1}$. Chcieliśmy sprawdzić, czy studenci zauważają zależność między zakończeniem tematu fleksyjnego a wyborem właściwej końcówki $(-i /-y)$. Poprawnej odpowiedzi w grupie glottodydaktyków udzieliły tylko 4 osoby. Jest to zastanawiające, ponieważ problem ten dokładnie omawiany jest zaraz na początku kursu metodyki, a występowanie końcówki $-i$ po temacie fleksyjnym zakończonym na $-k /-g$ pokazywane jest jako stała zależność. Wśród nieglottodaktyków znajomość reguły była jeszcze mniejsza; właściwie odpowiedziały tylko dwie osoby. W obu grupach zdarzały się odpowiedzi zbyt ogólne lub tylko częściowo poprawne, np. i piszemy po głoskach tylnojęzykowych $k, g$, $h$; ponieważ sq zasady mówiqce o odmianie, $n p$. po jakiej literze będzie końcówka fleksyjna $-i / y^{2}$. Zdecydowanie błędne odpowiedzi (glottodydaktycy udzielili ich 14, nieglottodydaktycy 8) to, np.: niebieski to wyjątek, ponieważ należa do innej deklinacji, zależy od rodzaju (!). 12 nieglottodydaktyków i 4 glottodydaktyków nie udzieliło żadnej odpowiedzi.

Istnienie różnicującej dobór końcówki fleksyjnej kategorii żywotności w bierniku zauważyło 20 glottodydaktyków i 10 nieglottodydaktyków. Być może dobry wynik w pierwszej grupie uwarunkowany jest obecnością w programie nauczania studiów polonistycznych Kultury języka polskiego na II roku studiów. Nieglottodydaktycy nie mieli szansy uczestniczyć w tych zajęciach. W obu grupach zbyt ogólnych lub częściowo poprawnych odpowiedzi udzieliło po 4 ankietowanych, np. Stowo komputer ma taka sama forme w B i w M; komputer to zapożyczenie, a wyraz syn odnosi się do rzeczownika żywotnego; biernik odpowiada na pytania kogo? co? Pojawiły się tylko dwie błędne odpowiedzi (w grupie nieglottodydaktyków): komputer rodzaj niemęskoosobowy, syn rodzaj męski; komputer to zapożyczenie, neologizm w porównaniu do stowa syn. Odpowiedzi nie udzieliło 2 studentów glottodydaktyków i 10 nieglottodydaktyków.

Na początku kursu Metodyki nauczania języka polskiego jako obcego 2 silnie akcentuje się rolę zaimka to w schematach składniowych (to jest + rzeczownik w mianowniku, jest + rzeczownik w narzędniku). Dziwi więc fakt, że tylko 8 glottodydaktyków i 5 nieglottodydaktyków umiało rozpoznać ukrytą w pytaniu zasadę. Aż 12 glottodydaktów i 3 nieglottodydaktów udzieliło nieprawidłowej odpowiedzi, np. dziewczyna narzuca konstrukcję przymiotnikowa, to wprowadza równorzędność. Przykładem odpowiedzi zbyt ogólnej jest: różne konstrukcje,

${ }^{1}$,Wygłos palatalny (miękki) to kwestia słownika, a nie systemu gramatycznego, dlatego nie można go przewidzieć. Po $p$ - np. może następować zarówno -i (głupi), jak i -y (tępy)" (Madelska, Warchoł-Schlottmann 2008, s. 104). W przypadku przymiotników zakończonych na - $k$ lub - $g$ zasada palatalności zachodzi bezwyjątkowo.

${ }^{2} \mathrm{~W}$ artykule zachowano oryginalną postać graficzną odpowiedzi. 
różne przypadki. Odpowiedzi typu końcówka przymiotnika zawsze powinna być dopasowana do końcówki rzeczownika mogą zdradzać brak istnienia świadomości problemu gramatycznego pomimo pokazania go w ankiecie na konkretnym przykładzie. Duży niepokój budzi fakt, że odpowiedź taka pojawiła się w grupie glottodydaktyków.

Zasadę negacji dopełnienia bliższego postawionego $\mathrm{w}$ bierniku ${ }^{3}$ umiało poprawnie wskazać 12 glottodydaktów i tylko 6 nieglottodydaktyków. Niepełnych odpowiedzi udzieliło 7 glottodydaktyków i 8 nieglottodydaktyków. Najczęściej powtarzające się odpowiedzi skupiały się na konkretnym (podanym w pytaniu ankietowym) czasowniku lubić $+B$, nie lubić $+D$. Odpowiadający nie byli w stanie sformułować ogólnej reguły. 8 nieglottodydaktyków i 2 glottodydaktyków nie odpowiedziało na pytanie w ogóle. Podobna liczba ankietowanych (5 glottodydaktyków i 4 nieglottodydaktyków) udzielała błędnych lub niezrozumiałych uzasadnień, np. $w$ bierniku rodzaju żeńskiego zawsze będzie -ę, ze względu na inny przypadek, w którym występuje wyraz (jest inna końcówka fleksyjna).

Cztery kolejne pytania podejmowały problematykę wyrażeń z przyimkami. Dwa dotyczyły doboru przyimka w zależności od kategorii semantycznej (np. przyimki oznaczające miejsce lub cel), dwa kolejne zróżnicowania syntaktycznego w użyciu przyimków (tzw. przyimki statyczne i dynamiczne). W przypadku pytań o przyimki statyczne i dynamiczne glottodydaktycy nie wyróżnili się wiedzą na tle nieglottodydaktyków. W pytaniu o dystrybucję przyimka na (Kasia pojechała na grzyby [biernik], ale Kasia była na grzybach [miejscownik]) prawidłowo odpowiedziało 4 glottodydaktyków i 5 nieglottodydaktyków, natomiast w pytaniu o przyimek nad (Magda opalała się nad rzeka [narzędnik], ale Magda poszła nad rzekę [biernik]) 4 glottodydaktyków i 4 nieglottodydaktyków ${ }^{4}$. W grupie nieglottodydaktyków przeważali studenci, którzy w ogóle nie odpowiedzieli na analizowane pytania (pytanie o przyimka $n a-6$ glottodydaktyków i 18 nieglottodydaktyków; pytanie o przyimek nad - 8 glottodydaktyków i 19 nieglottodydaktyków). Glottodydaktycy częściej próbowali udzielić odpowiedzi, ale też częściej odpowiadali błędnie (pytanie o przyimek $n a-6$ glottodydaktyków i 1 nieglottodydaktyk; pytanie o przyimek nad - 8 glottodydaktyków i żaden nieglottodydaktyk), np. pojechała aspekt dokonany, byla aspekt niedokonany; jest to zwiazane z deklinacja. Jako przykład odpowiedzi niekonkretnej (pytanie o przyimek $n a-10$ glottodydaktyków i 2 nieglottodydaktyków; pytanie o przyimek nad - 6 glottodydaktyków i 3 nieglottodydaktyków) można podać: pojechać $+B$, być + Msc; bo takich przypadków wymagaja czasowniki.

3 Przy negacji dopełnienia bliższego czasowników przechodnich biernik musi zostać zastąpiony dopełniaczem, np. Lubię kawę, ale Nie lubię kawy, Noszę torebkę, ale Nie noszę torebki, Czytam książkę, Nie czytam książki.

4 Dodatkowa analiza ankiet pozwoliła stwierdzić, że prawidłową odpowiedź wśród nieglottodydaktyków podali studenci filologii rosyjskiej, którzy zetknęli się z podobnym zjawiskiem podczas nauki języka rosyjskiego. 
Semantyczne uwarunkowania dystrybucji przyimków okazały się bardziej zauważalne dla studentów glottodydaktyków. Właściwe zależności: do + budynek, $n a+$ otwarta przestrzeń oraz $d o+$ miejsce, $n a+$ cel wskazało odpowiednio 12 glottodydaktyków, 5 nieglottodydaktyków i 12 glottodydaktyków i 10 nieglottodydaktyków. W odpowiedziach niepełnych respondenci zauważali jedynie związek przyimka do z miejscem (4 glottodydaktyków i 2 nieglottodydaktyków), brakowało wytłumaczenia dla użycia przyimka $n a$. Kolejny raz nieglottodydaktycy nie podjęli próby wyjaśnienia zagadnienia (w pytaniu: do szkoty / na boisko - 6 glottodydaktyków i 17 nieglottodydaktyków; w pytaniu: do baru / na piwo - 2 glottodydaktyków i 11 nieglottodydaktyków). Tym samym więcej błędnych odpowiedzi pojawiło się w grupie studentów po specjalizacji (pytanie: do szkoły I na boisko - 4 glottodydaktyków, 2 nieglottodydaktyków; w pytaniu: do baru / na piwo - 8 glottodydaktyków i 3 nieglottodydaktyków), np. rodzaj nijaki-na, r. żeński - do; do - szkoła w sensie bardziej rzeczywistym.

W kolejnym pytaniu ankietowani byli proszeni o wyjaśnienie różnic w konstrukcjach syntaktycznych z liczebnikiem (Dlaczego mówimy: 27 lat , ale 42 lata). 14 glottodydaktyków i 6 nieglottodydaktyków prawidłowo wytłumaczyło to zagadnienie. 7 glottodydaktyków i 4 nieglottodydaktyków udzieliło poprawnej, choć nieprecyzyjnej odpowiedzi, np. 2-4 lata, 5 - lat, 7 lat, 2 lata. Po raz kolejny w grupie nieglottodydaktyków dominująca była sytuacja, której nie udzielono jakiejkolwiek odpowiedzi (12 nieglottodydaktyków i 2 glottodydaktyków). Niestety, choć nie było ich wiele (3 glottodydaktyków i 4 nieglottodydaktyków), zdarzały się odpowiedzi nieprawidłowe, wręcz absurdalne: Ponieważ do liczebników parzystych dodajemy końcówkę - a; nieparzyste lat, parzyste lata; 7 rodzaj męski, więc lat, 2 rodzaj żeński, więc lata. Pomijając te nonsensowne uzasadnienia, duża liczba trafnych odpowiedzi pokazuje, że studenci w przypadku prostych zagadnień gramatycznych są w stanie stworzyć uogólniający wniosek.

Najmniej problemów nastręczyło pytanie o przymiotnik w wyrażeniu z rzeczownikiem rodzaju męskiego zakończonym na - $a$ (Dlaczego uczący się języka polskiego jako obcego może popełnić błąd i powiedzieć: Jan jest dobrạ mężczy$z n q$ ?). 21 glottodydaktyków i 17 nieglottodydaktyków udzieliło prawidłowej odpowiedzi. Studenci potrafili wskazać źródło błędu, pisząc na przykład, że rzeczownik mężczyzna odmienia się w liczbie pojedynczej wedtug deklinacji żeńskiej, co mogłoby sugerować żeńska końcówkę przymiotnika. Wśród 5 niepełnych odpowiedzi (2 glottodydaktyków i 3 nieglottodydaktyków) można przytoczyć np.: ze względu na mylaca formę „mężczyzna". Nie pojawiły się odpowiedzi błędne, natomiast 3 glottodydaktyków i 6 nieglottodydaktyków w ogóle nie odniosło się do problemu.

Dodatkowo w ankiecie zamieszczone zostały dwa pytania, które wykraczały poza przyjęty w kwestionariuszu schemat. Studentów poproszono o określenie przypadka lub rodzaju podanych rzeczowników. Zadania te nie dotyczyły więc 
stricte gramatyki funkcjonalnej. Określanie przypadka, rodzaju wyrazu danej formy to dla nauczyciela języka polskiego umiejętność elementarna. W większości studenci nie mieli problemów z rozpoznaniem formy deklinacyjnej, choć zdarzały się pomyłki. Dotyczyło to głównie form miejscownika ( $p o$ parku), narzędnika (pod stolem) i celownika ( $k$ u bramie). Najprawdopodobniej ankietowani posiłkowali się pytaniem gdzie, ponieważ często zamiast na narzędnik lub celownik wskazywali na miejscownik. Odwrotne sytuacje (podanie innych przypadków zamiast miejscownika) nie zdarzały się. Kłopotliwe były też te formy, które opierały się na synkretyzmie końcówek biernika i dopełniacza liczby mnogiej (fotografuję synów) oraz mianownika i biernika liczby pojedynczej (mam zadanie) błędnie identyfikowane przez studentów jako formy dopełniacza lub mianownika.

Rozpoznanie rodzaju rzeczowników okazało się trudniejszym zadaniem. Kłopotów przysparzały przede wszystkim rzeczowniki w liczbie mnogiej, takie jak: studentki, inżynierowie, koty. Po pierwsze studenci przenosili bezrefleksyjnie rodzaj z liczby pojedynczej na mnogą. I tak: studentki były rodzaju żeńskiego, inżynierowie i koty męskiego. Po drugie błędnie pojmowali kategorię męskoosobowości, doszukując się rodzaju męskoosobowego w rzeczowniku studentki lub koty. Być może było to spowodowane myleniem kategorii osobowości z kategorią żywotności (problem ten zaobserwowano również podczas zajęć metodycznych na specjalizacji). Zagadnienie jest ważne, gdyż kategorie żywotności i osobowości są trudne dla cudzoziemców. Nauczyciel powinien więc sam doskonale je rozumieć i potrafić wythumaczyć. Potwierdzeniem wskazanego problemu jest również fakt, że tylko 8 osób (z 52 ankietowanych) poprawnie określiło rodzaj wyrazu chłopaki jako niemęskoosobowy. Pozostali wskazywali na wszystkie inne rodzaje: męski, męskoosobowy, nijak czy żeński. Pojawiały się nawet odpowiedzi, że jest to rzeczownik dwurodzajowy (męskoosobowy i niemęskoosobowy). Zdarzały się również, choć na szczęście były one nieliczne, wskazania absurdalne, jak: kot - rodzaj nijaki lub żeński, student$k i$ - rodzaj męski. Prawie niezauważone zostało zagadnienie dwurodzajowości rzeczowników (odnoszące się do przedstawicieli obu płci, stopni i tytułów naukowych oraz epitetów rzeczownikowych zakończone na -a) (Jadacka 2007, s. 17-18). Tylko jedna osoba zauważyła, że za dwurodzajowy należy uznać rzeczownik doktor, 6 ankietowanych prawidłowo podało rodzaj (męski i żeński) leksemu fajtłapa. Istota kategorii rodzaju uświadamiana jest cudzoziemcom już na pierwszych lekcjach języka polskiego, tym bardziej, że jest to cecha przysługująca niemal wszystkim odmiennym częściom mowy . Dwurodzajowość pojawia się chociażby przy nazwach zawodów, a kategorie żywotności i osobowości w perspektywie glottodydaktycznej są istotne już przy mianowniku, bierniku czy dopełniaczu.

${ }^{5} \mathrm{Z}$ wyjątkiem zaimków rzeczownych $j a, t y, m y$, wy oraz zaimka zwrotnego się (WSPP, s. 1658). 
Błędy w określaniu przypadka i rodzaju zastanawiają, ponieważ umiejętność ta ćwiczona jest już na początkowych etapach edukacji w szkole podstawowej i utrwalana podczas zajęć gramatycznych (nauki o języku) w gimnazjum i szkole ponadgimnazjalnej. Są to braki, których nie powinien mieć słuchacz studiów filologicznych.

Analiza wyników ankiet nie napawa optymizmem. Na zajęciach z metodyki nauczania jpjo 2 bardzo dokładnie analizuje się każde $\mathrm{z}$ poruszanych $\mathrm{w}$ kwestionariuszu zagadnień. Studenci zachęcani są, by samodzielnie, na podstawie dostarczonych przez wykładowcę materiałów, odkrywać reguły i analogie, a także konteksty komunikacyjne, w których wykorzystuje się dane zjawiska gramatyczne. Co prawda wyniki analizy ankiet w grupie studentów, którzy ukończyli specjalizację są lepsze niż w grupie studentów nieglottodydaktyków, czyli tych, którzy dopiero rozpoczęli specjalizację, jednak nadal nie jest to wynik zadowalający. Tylko w trzech pytaniach poprawnych odpowiedzi było więcej niż $50 \%$. Najgorzej wypadły pytania dotyczące dystrybucji przyimków i, co wyjątkowo zaskakujące, pytanie o końcówki przymiotnika w rodzaju męskim. Zauważono, że studenci nieglottodydaktycy zdecydowanie częściej unikali udzielenia odpowiedzi, pozostawiając puste miejsce $\mathrm{w}$ kwestionariuszu. W pięciu pytaniach na dziesięć dotyczących zagadnień z zakresu gramatyki funkcjonalnej odpowiedzi nie podało więcej niż 50\% ankietowanych. Niepokoi również obecność odpowiedzi nonsensownych, zupełnie niejasnych lub całkowicie błędnych. Z egzemplifikacji, które nie pojawiały się wcześniej, można przytoczyć: bo mamy durna fleksję; nigdy nie umiałam tego wytlumaczyć, dlatego nie chcę uczyć cudzoziemców; „niebieski” nie ma końcówki fleksyjnej. Część z nich ewidentnie świadczy o braku samej świadomości istnienia problemów gramatycznych i możliwości systemowego wyjaśnienia analizowanych zjawisk, np.: bo taka jest odmiana.

Ogólne zestawienie poszczególnych typów odpowiedzi studentów glottodydaktyków i nieglottodydaktyków przedstawia się następująco:

Wykres 1. Porównanie poszczególnych typów odpowiedzi z zakresu fleksji imiennej dla obu grup

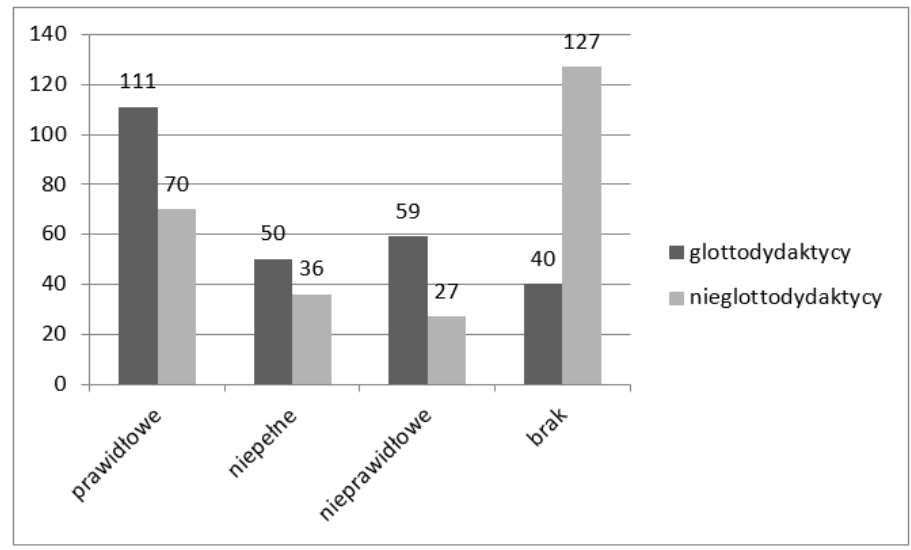

Źródło: opracowanie własne 
Przedstawione w artykule problemy pokazują konieczność szczegółowszego zbadania zagadnienia świadomości lingwistycznej nauczycieli języka polskiego jako obcego/drugiego. Wydaje się wręcz, że świadomość językowa a nawet świadomość lingwistyczna to za mało w przypadku glottodydaktyka. Specyfika pracy lektora wymusza inne spojrzenie na system językowy. Tym samym zasadne wydaje się pójście w głąb - wprowadzenie do rozważań pojęcia glottodydaktycznej świadomości lingwistycznej. Glottodydaktyczna świadomość lingwistyczna to nie tylko znajomość zasad budowy języka oraz reguł systemowych istotnych dla sprawnego i poprawnego posługiwania się nim (por. Bugajski 2007). Jest to świadomość ukierunkowana na nauczanie cudzoziemców, wymagająca innego spojrzenia na język, takiego, którego nie doświadcza jego rodzimy użytkownik, a nawet językoznawca (specjalista). Glottodydaktyczną świadomość lingwistyczną rozumiemy jako eksplicytną wiedza o strukturze systemu językowego niezbędną do nauczania języka jako obcego; umiejętność zauważenia reguł, zależności, analogii, tak by w praktyce móc stosować je w nauczaniu języka polskiego jako obcego. Dotyczy ona najprostszych elementów systemu i korelacji pomiędzy nimi.

Glottodydaktyczną świadomość lingwistyczną (GŚL) można traktować jako dopełnienie świadomości lingwistycznej. Nie wszystkie problemy gramatyczne (np. semantyczna dystrybucja przyimków) są istotne dla językoznawców nieglottodydaktyków, gdyż nie sprawiają one problemu rodzimym użytkownikom języka, a tym samym nie wchodzą w obszar głównych zainteresowań normatywistów. Natomiast z punktu widzenia glottodydaktyka umiejętność wyjaśnienia tych zagadnień jest kluczowa. Wytłumaczenie to jednak musi być proste, systemowe, jednoznaczne. Te najważniejsze problemy często dotyczą właśnie zagadnień najprostszych, nad którymi rodzimy użytkownik polszczyzny nie zastanawia się, bo nie musi. Rozwijanie GŚL, to kształcenie w zakresie językoznawstwa glottodydaktycznego, posługującego się, jak to zauważa m.in. Iwona Słaby-Góral (2014) własnym opisem teoretycznym języka dla potrzeb przekazywania wiedzy o nim. Analiza ankiet pokazała, że nie jest to zadanie łatwe. Studentom trudno jest spojrzeć na język z perspektywy osoby uczącej się, z zewnątrz. Kiedy sami są w tym języku zanurzeni, pewne struktury gramatyczne są dla nich naturalne, a mechanizm ich funkcjonowania i istota użycia stają się niezauważane i nieuświadamiane.

\section{BIBLIOGRAFIA}

Bakuła K., 2012, O świadomości językowej, krytycznej świadomości językowej i nauczaniu języka, „Acta Universitatis Wratislaviensis. Kształcenie Językowe”, nr 10(20), s. 9-20.

Bugajski M., 2007, Język w komunikowaniu, Warszawa.

Jadacka H., 2007, Kultura języka polskiego. Fleksja, słowotwórstwo, składnia, Warszawa.

Maćkowiak K., 2005, Historyczna świadomość językowa w badaniach lingwistycznych, ,Język Polski”, z. 1, s. 1-7. 
Madelska L., Warchoł-Schlottmann M., 2008, Odkrywamy język polski. Gramatyka dla uczacych (się) języka polskiego jako obcego, Kraków.

Markowski A., 2005, Kultura języka polskiego. Teoria. Zagadnienia leksykalne, Warszawa.

Perużyńska I., 2005, Świadomość językowa studentów filologii polskiej Pomorskiej Akademii Pedagogicznej w Stupsku, „Słupskie Prace Filologiczne. Seria Filologia Polska”, z. 4, s. $215-233$.

Słaby-Góral I., 2014, Nauczyciel uczy się przez całe życie, „Acta Universitatis Lodziensis. Kształcenie Polonistyczne Cudzoziemców”, t. 21, E. Pałuszyńska, B. Grochala, I. Dembowska-Wosik, M. Wojenka-Karasek (red.), s. 229-249.

Wielki stownik poprawnej polszczyzny PWN, 2006, pod. red. A. Markowskiego, Warszawa (=WSPP).

Zgółka T., 1996, Warstwy świadomości językowej, w: E. Sękowska (red.), Świadomość językowa - kompetencja-dydaktyka, Warszawa, s. 13-19.

Magdalena Karasek, Mateusz Gaze

\section{METALINGUISTIC AWARENESS OF THE (PROSPECTIVE) TEACHERS \\ OF POLISH AS A FOREIGN LANGUAGE - SOME REMARKS ON THE KNOWLEDGE OF DECLENSION}

Keywords: functional grammar, metalinguistic awareness, teacher competences, declension, teaching Polish as a foreign language

Abstract. The article concerns the issue of linguistic awareness among students who attend the program for the prospective teachers of Polish as a foreign language at the Faculty of Philology at the University of Lodz. In the text, we present and comment on the results of a survey study among 52 students. The survey consisted of questions on basic issues of functional grammar of the Polish language in the area of declension, which are presented to learners of Polish as a foreign language. The analysis led to the proposal to introduce the notion of didactic metalinguistic awareness, related to the peculiar character of foreign language teaching, which would complement the metalinguistic awareness. 